\title{
NO EVIDENCE OF ASSOCIATION BETWEEN APO E POLYMORPHISM AND BMI AND LIPIDS PROFILE IN TURKMEN POPULATION
}

\author{
Eshghinia $\mathrm{S}^{* 1}$, Ahani Azari $\mathrm{M}^{2}$, Samaei $\mathrm{NM}^{3}$, Mamizade $\mathrm{N}^{2}$ \\ 1: MD,PhD of nutrition, Metabolic Disorders Research Center, Golestan University of Medical Sciences, \\ Gorgan, Iran. \\ 2: Faculty of Animal Sciences, Gorgan University of Agricultural Sciences and Natural Resources, \\ Gorgan, Iran \\ 3: Department of Human Genetics, Golestan University of Medical Sciences, Gorgan, Iran
}

\begin{abstract}
Apolipoprotein $\mathrm{E}(\mathrm{apoE})$ is a glycoprotein that plays an essential role in lipid transport and metabolism. The present study purposed to determine the distribution of apoE alleles in a Turkman population and its association with lipid profile. In a cross-sectional study 354 healthy Turkman were recruited. Fasting blood samples were collected for biochemical tests and DNA extracting. Genomic DNA was amplified using PCR-RFLP method. The resulting fragments of PCR product digestion were detected by polyacrylamide gel electrophoresis. This study showed that $\varepsilon 3$ allele and E3/E3 genotype are the most common allele and genotype, while $\varepsilon 2$ and $\varepsilon 4$ alleles had lower frequencies, respectively. Two homozygote genotypes E2E2 and E4E4 were not detected in our sample. Results didn't confirm any association between apo E polymorphism with lipids concentration in Turkmen population.
\end{abstract}

Keywords: Apolipoprotein E; Polymorphysm; Genetics; Lipids.

\section{Council for Innovative Research}

Peer Review Research Publishing System

\section{Journal: JOURNAL OF ADVANCES IN BIOTECHNOLOGY}

Vol. 5, No. 1

www.cirjbt.com , jbteditor@gmail.com 


\section{INTRODUCTION}

Coronary artery disease and stroke are leading causes of morbidity and mortality worldwide (Lopez et al. 2006). Some metabolic factors such as elevated levels of fasting plasma triglyceride (TG) and total cholesterol(TC), abnormally low high-density lipoprotein (HDL-C) levels and elevated low-density lipoprotein (LDL-C) concentrations are well-established risk factors for atherosclerosis and coronary heart disease (CHD) (Vanuzzo et al. 2008; Kim et al. 2005; Hokanson et al. 1996). It is also well known that blood lipid concentration is determined by both environmental and genetic factors. ApoE is an important structural constituent of several serum lipoprotein classes that its genetic variation can affect its anti atherosclerotic effects (Davignon et al. 1999). Apolipoprotein E (apoE) is a $34 \mathrm{KD}$ glycoprotein with 299 amino acids that is mainly synthesized in liver. Apo $E$ has an essential role in the lipid metabolism via its role in lipid transport. (Ordovas et al. 2000; Eichner et al. 2002; Dallongeville et al. 1992).

The common variants of apo $\mathrm{E}$ polymorphism include major alleles $\varepsilon 2$, $\varepsilon 3$, and $\varepsilon 4$ located on chromosome 19 and six corresponding genotypes (E3/E3, E3/E4, E2/E3, E4/E4, E2/E4, and E2/E2) (Das et al. 1985; Zannis et al. 1982).

Previous studies have shown that these three alleles have quantitative effects on lipid and lipoprotein levels. $\varepsilon 2$ allele is associated with low levels of total cholesterol (TC), low density lipoprotein (LDL-C), and apoprotein B (apo B), whereas $\varepsilon 4$ allele has correlation with the opposite effects (Davignon et al. 1988; Eichner et al. 2002; Braeckman et al. 1996). In some studies, a positive association has been showed between $\varepsilon 2$ allele and serum concentrations of HDL-C (Mahley et al. 2000). Apo $\varepsilon 3$ is the most frequent allele in all studied populations (Mahley et al. 2000).

In study of 198 healthy candidates in Southern Iran, frequencies of apoE alleles were: $6.3,88.6$ and $5.1 \%$ for $\varepsilon 2$, ع3 and $\varepsilon 4$, respectively (Bazrgar et al. 2008). In another study of 198 healthy Kurdish in west of Iran, frequencies of apoE alleles were: $6.66,87.87$ and $5.45 \%$ for $\varepsilon 2, \varepsilon 3$ and $\varepsilon 4$, respectively (Vaisi-Raygani et al. 2007). The aim of present study was to determine apo $\mathrm{E}$ gene polymorphism and evaluate its effect on plasma lipids in Turkmen population in east north of Iran.

\section{MATERIALS AND METHODS}

\section{1-Studied population}

In a randomly sampled cross-sectional study of 354 healthy Turkman, referred to Health Center Lab for premarried tests in 3 cities (Gonbad, Kalale, Azadshahr) located in North Eastern Iran, South East of the Caspian Sea were recruited in this study in period of May to August 2011. All selected subjects Have had at least two generations from "Turkman" background. The inclusion criteria were all of subjects who interest to enroll in the study. The history of medication affected lipid metabolism determined as exclusion criteria. After obtaining informed consent, a checklist containing personal and demographic characteristics was completed for each patient. Height, weight and blood pressure were measured and recorded. Body Mass Index (BMI) was calculated based on the following formula; body weight /square height $(\mathrm{kg} / \mathrm{m} 2)$.

Fasting venous blood was collected from each subject, $2 \mathrm{ml}$ in tubes with EDTA for DNA extracting and $5 \mathrm{ml}$ without anticoagulant for biochemical tests. After centrifugation and separation, all samples were stored at $-70{ }^{\circ} \mathrm{C}$ until analysis.

\section{2-Laboratory methods}

Serum glucose, total cholesterol, HDL-C, and triacylglycerol concentrations were measured using enzymatic colorimetric method by using Pars Azmoon kits (Pars Azmoon Co., Tehran, Iran). LDL-C concentration was performed using the Friedewald equation.

\section{3-ApoE genotype determination}

To extract Genomic DNA from the peripheral blood leukocytes, standard kit (Diatom DNA prep 100 - Genfanavaran co., Tehran) was used. Quality and quantity of extracted DNA was determined by spectophotometric and agarose gel(0.8\%) electrophoresis techniques.

\section{4-PCR method}

A 224bp fragment of this gene was amplificated using polymerase chain reaction (PCR) method. To optimize PCR condition actors including annealing temperature, number of cycles, step durations and DNA concentration were altered. PCR reaction contained $3 \mu \mathrm{LNA}(75 \mathrm{ng} / \mu \mathrm{l}), 7.5 \mu \mathrm{l}$ master mix, $0.5 \mu \mathrm{mol}$ of each primer and some deionized water up to final volume of $15 \mu \mathrm{l}$. Sequence of used primers, suggested by Yin et al (2008)are showed in table 1.

Because of low quality DNA, PCR regime included 2 consecutive programs as presented in table 2. Electrophoresis on $2.5 \%$ gel was used to confirm authenticity of PCR product.

Table 1-Sequence of used primers for amplificating the investigated gene

$\begin{array}{ll}\text { Forward: } & \text { 5'-ACAGAATTCGCCCCGGCCTGGTACAC-3' } \\ \text { Reverse: } & \text { 5'- TAAGCTTGGCACGGCTGTCCAAGGA-3' }\end{array}$


Table2- PCR program used in this study

\begin{tabular}{|lccc|}
\hline Steps & Temp. $\left({ }^{\circ} \mathrm{C}\right)$ & Duration & Num. of cycles \\
\hline -Primary denaturation & 95 & $5^{\prime}$ \\
of DNA & & \\
-Denaturation of DNA & 95 & $65^{\prime \prime}$ \\
-Annealing & 61.8 & $65^{\prime \prime}$ \\
-Synthesis & 72 & $90^{\prime \prime}$ \\
-Denaturation of DNA & 95 & $60^{\prime \prime}$ \\
-Annealing & 61.8 & $60 "$ \\
-Synthesis & 72 & $90 "$ \\
-Final synthesis & 72 & $8^{\prime \prime}$ & 24 \\
& & & \\
\hline
\end{tabular}

\section{5-Digesting Reaction}

After PCR , $5 \mu$ l of the amplificated fragment was digested by 10 units of Hhal endonuclease enzyme following the factory protocol as showed in table 3. Samples were incubated for 16 hours at $37^{\circ} \mathrm{C}$. Digestion products were run on $6 \%$ polyacrylamide gel in $(60 \mathrm{~V} / 160 \mathrm{Min})$ electrophoresis and then were stained using optimized silver staining method (Benbouza et al. 2006) as presented in table 4.

Table 3- Protocol of digesting APO E gene

\begin{tabular}{lrrlll}
\hline Content & & & Used concentration & Volume & \\
\hline Enzyme & $(10 \mathrm{U} /$ & $\mu \mathrm{l})$ & $10 \mathrm{U}$ & $0.1 \mu \mathrm{l}$ & \\
Buffer & & & $10 \mathrm{X}$ & $2 \mu \mathrm{l}$ & \\
$\mathrm{PCR}$ & & product & & $5 \mu \mathrm{l}$ & \\
$\mathrm{H} 2 \mathrm{O}$ & & - & $2.9 \mu \mathrm{l}$ & \\
& & & & & Total $=10$
\end{tabular}

Table 4- Steps of fast silver nitrate staining method

\begin{tabular}{|llc|}
\hline Step & solution & duration(Min) \\
\hline 1-Fixation & 1CC ethanol $100 \%+$ & 5 \\
$(100 \mathrm{CC})$ & $100 \mu$ l acetic acid $+\mathrm{H} 2 \mathrm{O}$ & 2 \\
2-Washing & Distilled $\mathrm{H} 2 \mathrm{O}$ & 10 \\
3- Staining & Nitrate silver $(0.1 \mathrm{~g})^{+}$ & \\
(100CC) & $\mathrm{H} 2 \mathrm{O}$ & 2 \\
4-Washing & Distilled $\mathrm{H} 2 \mathrm{O}$ & $15-20$ \\
5- Developing & $\mathrm{NaOH}(1.5 \mathrm{~g})+$ Formaldehyde & \\
( 100CC) & $500 \mu \mathrm{l}+\mathrm{H} 2 \mathrm{O}$ & 2 \\
6-Washing & Distilled $\mathrm{H} 2 \mathrm{O}$ & \\
& & \\
\hline
\end{tabular}

\section{6-Genotyping method}

Determining genotype of the investigated groups was performed based on presented information in table 5 . 
Table 5- Size of digestion reaction concerning to different genotypes of APO E gene

\begin{tabular}{|lc|}
\hline Genotypes & Fragment size(bp) \\
\hline E2E3 & $91,83,48,38,35$ \\
E2E4 & $91,83,72,48,38$ \\
E3E3 & $91,48,38,35$ \\
E3E4 & $91,72,48,38$ \\
& \\
\hline
\end{tabular}

\section{7-Statistical analysis}

Strength of association between different variables and Apo E gene polymorphism was estimated by Chi-square and logistic regression using SPSS software, version 16. $\mathrm{P} \leq 0.05$ was considered as significant in statistical analysis.

This study supported by Metabolic Disorders Research Center, Ischemic Disorders Research Center Golestan University of Medical Sciences and was approved by the Ethics Committee of Golestan University of Medical Sciences (No 312989111013) and Vice Presidency for research and Technology of Gorgan University of Agricultural Sciences and Natural Resources.

\section{RESULTS}

344 subjects were participated in this study. The mean age of them was $27.8 \pm 8.4$ years. $35 \%(n=121)$ of them were male. Neither of them gets medications affected on glucose or lipid metabolism. Baseline characteristics of participants have shown in table 6 . The mean of TG in men $(99.43 \pm 99.32)$ was significantly higher than women $(79.03 \pm 50.19)$. The level of HDL cholesterol in females was higher than males $(P<0.0001)$.

Table 6: Basic characteristic and biochemical indexes of participants $(n=344)$

\begin{tabular}{|l|l|l|l|l|}
\hline \multirow{2}{*}{ Index } & \multicolumn{2}{|l|}{ Mean \pm SD } & \multirow{2}{*}{-value } \\
\cline { 2 - 5 } & Total $(\mathrm{n}=344)$ & Male $(\mathrm{n}=121)$ & Female(n=223) & \\
\hline Age $(\mathrm{yr})$ & $27.83 \pm 8.36$ & $28.36 \pm 8.35$ & $27.56 \pm 8.38$ & 0.396 \\
\hline BMl $(\mathrm{kg} / \mathrm{m} 2)$ & $25.02 \pm 6.88$ & $24.77 \pm 8.06$ & $25.16 \pm 6.17$ & 0.284 \\
\hline TG $(\mathrm{mg} / \mathrm{dl})$ & $86.22 \pm 71.99$ & $99.43 \pm 99.32$ & $79.03 \pm 50.19$ & 0.001 \\
\hline T Chol (mg/dl) & $179.30 \pm 54.27$ & $172.30 \pm 52.77$ & $183.11 \pm 54.81$ & 0.076 \\
\hline HDL $(\mathrm{mg} / \mathrm{dl})$ & $35.40 \pm 8.53$ & $31.67 \pm 8.14$ & $37.44 \pm 8.06$ & 0.0001 \\
\hline LDL $(\mathrm{mg} / \mathrm{dl})$ & $126.65 \pm 52.11$ & $120.74 \pm 51.71$ & $129.87 \pm 52.16$ & 0.12 \\
\hline
\end{tabular}

BMI: Body Mass Index, TG: Triglyceride, TChol: Total Cholesterol, HDL: high density lipoprotein, LDL: Iow density lipoprotein. Independent sample T. test was used as analytic test to compare means between two sexes.

The distribution of Apo E genotypes and alleles is shown in Table 7. As shown in table 7, the most frequent genotype is E3E3 and allele is $\varepsilon 3$. Frequencies of $\varepsilon 2$ and $\varepsilon 4$ were 11.63 and $6.83 \%$ respectively. Two homozygote genotypes of E2E2 and E4E4 were not detected in our samples. As shown in table 8, there is no statistically significant difference in BMI and lipid concentration between different genotypes of apo $E$.

Table 7: Distribution of Apo E genotype frequencies and alleles

\begin{tabular}{|l|l|l|l|l|l|l|l|l|l|}
\hline \multicolumn{2}{|l|}{ Genotypes distribution N=344 } & \multicolumn{3}{l|}{ Alleles $n=688$} \\
\hline E4E4 & E3E4 & E3E3 & E2E4 & E2E3 & E2E2 & $\varepsilon 4$ & $\varepsilon 3$ & $\varepsilon 2$ \\
\hline $\mathrm{n}$ & 0 & 39 & 225 & 8 & 72 & 0 & 47 & 561 & 80 \\
\hline$\%$ & 0 & 11.34 & 65.41 & 2.32 & 20.93 & 0 & 6.83 & 81.54 & 11.63 \\
\hline
\end{tabular}


Table 8: The mean of BMI and lipids concentration in different genotypes

\begin{tabular}{|l|l|l|l|l|l|l|}
\hline Genotypes & $\mathrm{N}$ & $\begin{array}{l}\text { BMl(kg/m2) } \\
\text { Mean } \pm \text { SD }\end{array}$ & $\begin{array}{l}\text { TG }(\mathrm{mg} / \mathrm{dl}) \\
\text { Mean } \pm \text { SD }\end{array}$ & $\begin{array}{l}\text { Chol. }(\mathrm{mg} / \mathrm{dl}) \\
\text { Mean } \pm \text { SD }\end{array}$ & $\begin{array}{l}\text { HDL }(\mathrm{mg} / \mathrm{dl}) \\
\text { Mean } \pm \text { SD }\end{array}$ & $\begin{array}{l}\text { LDL }(\mathrm{mg} / \mathrm{dl}) \\
\text { Mean } \pm \text { SD }\end{array}$ \\
\hline E2E4 & 8 & $25.46 \pm 5.38$ & $80.19 \pm 52.00$ & $167 \pm 55.92$ & $30 \pm 7.87$ & $120.96 \pm 50.69$ \\
\hline E2E3 & 72 & $24.39 \pm 5.30$ & $85.98 \pm 49.24$ & $187.22 \pm 55.21$ & $36 \pm 9.4$ & $134.02 \pm 52.51$ \\
\hline E3E3 & 225 & $24.82 \pm 5.89$ & $86.24 \pm 82.19$ & $175.65 \pm 54.62$ & $35.36 \pm 8.3$ & $123.03 \pm 52.61$ \\
\hline E3E4 & 39 & $26.18 \pm 12.48$ & $91.12 \pm 49.61$ & $188.55 \pm 51.43$ & $35.84 \pm 8.7$ & $134.49 \pm 50.69$ \\
\hline Total & 344 & $24.90 \pm 6.83$ & $86.59 \pm 72.42$ & $179.33 \pm 54.52$ & $35.43 \pm 8.58$ & $126.58 \pm 52.38$ \\
\hline $\begin{array}{l}\text { ANOVA (one way) } \\
\text { P value }\end{array}$ & 0.606 & 0.974 & 0.260 & 0.307 & 0.331 \\
\hline
\end{tabular}

\section{DISCUSSION}

on the polymorphism of apoE in several populations have demonstrated the presence of three common apoE alleles, e2, e3, and ApoE epidemiologic studies are interesting researches regarding to its association with cardiovascular diseases. Studies e4, which code for genetic isoforms and determine six different phenotypes.

Our study is the first report of ApoE polymorphism in Turkmen sub-population Northern Iran. In our population, we observed that E3 allele was the most common, followed by the E2 and E4 alleles respectively. These results are in agreement with previous findings in Iran (Bazrgar et al. 2008; Tabatabaei-Malazy et al. 2012; Bazzaz et al. 2010). In some of previous reports the frequency of E2 allele was rarer than E4 (Burman et al. 2009; Zende et al. 2013; Al-khedhairy 2004).

E4E4 and E2E2 genotypes are rarer genotypes in all studies. In this study the frequency of $\varepsilon 2$ allele was in high reported universal for human populations but homozygote E2E2 genotype was not seen in our population. Also the E4E4 genotype was not detected. It is an unexpected result because the intra-ethnic marriages are a tradition in Turkmen and we have awaited to detect these homozygote genotypes. The results of current study show no significant difference in TG, total cholesterol, LDL and HDL levels between different genotypes of ApoE. In reviewing the literature, several studies were found the association between ApoE genotypes and dyslipidemia as a important risk factor associated with atherosclerosis and coronary heart disease (Panza et al. 1999; Boulenouar et al. 2013).

In several studies Apo E4 allele has been linked to higher plasma lipids levels (Yin et al. 2013) and also has shown that the prevalence of the E4-containing phenotypes was significantly higher in subjects with cardiovascular and cerebrovascular diseases (Boulenouar et al. 2013; Haddy et al. 2002). In results of Zende et al study, was reported higher lipid level in group having E4 homozygous allele than other alleles (Zende et al. 2013). It is also demonstrated that the presence of Apo E2 can play a protective role against dyslipidemia 91 (Lehtinen et al. 1995; Mendes-Lana et al. 2007). A possible explanation for this difference might be that our samples were healthy and young. Moreover dyslipidemia is a multifactorial disorder, affected by genetic and environmental factors such as demographic characteristics, dietary habits, and lifestyle choices.

The current research was not specifically designed to evaluate environmental factors. Further experimental investigations are needed to determine the ApoE polymorphism in chronic diseases such as CHD, hyperlipidemia, obesity, diabetes, etc. Also Further research might investigate the role of environmental factors such as diet and physical activities in relation with ApoE polymorphism in pathogenesis of diseases related to serum lipids.

\section{CONCLUSION}

Our study showed that the ApoE epsilon polymorphism has not the expected impact on the plasma lipid profile in a Iranian Turkman population. However, due to the small sample size in most of the included studies and the selection bias existed in some studies, the results should be interpreted with caution.

\section{ACKNOWLEDGMENT}

The authors would like to acknowledge "Research Deputy" Golestan University of Medical Sciences and Vice Presidency for research and Technology of Gorgan University of Agricultural Sciences and Natural Resources for financial supports. We thank Mrs. Poursharifi, staff from biochemistry laboratory of medicine faculty for her technical help. We are grateful to all the families and research staff who participated in the study.

\section{Competing interests}

The authors declare that they have no competing interests 


\section{REFERENCES}

[1] Al-khedhairy AA (2004) Apolipoprotein E polymorphism in Saudis. Mol Biol Rep 31(4):257-260

[2] Bazrgar M, Karimi M, Fathzadeh M, Senemar S, Peiravian F, Shojaee A, Saadat M (2008) Apolipoprotein E polymorphism in Southern Iran: E4 allele in the lowest reported amounts. Mol Biol Rep Dec;35(4):495-9

[3] Bazzaz JT, Nazari M, Nazem H, Amiri P, Fakhrzadeh H, Heshmat R (2010) Apolipoprotein E gene polymorphism and total serum cholesterol level in Iranian population. J Postgrad Med 56: 173-175

[4] Benbouza H., Jacquemin J.M., Baudoin J.P., Mergeai G (2006) Optimization of a reliable, fast, cheap and sensitive silver staining method to detect SSR markers in polyacrylamide gels. Biotechnol. Agron. Soc. Environ 10(2):77-81

[5] Boulenouar H, Mediene Benchekor S, Meroufel DN, Lardjam Hetraf SA, Ouhaibi Djellouli H, Hermant X, Grenier-Boley B, Hamani Medjaoui I, Saidi Mehtar N, Amouyel P, Houti L, Meirhaeghe A, Goumidi L (2013) Impact of APOE gene polymorphisms on the lipid profile in an Algerian population. Lipids in Health and Disease, 25: 12:155

[6] Braeckman L, De Bacquer D, Rosseneu M, De Backer G (1996) Apolipoprotein E polymorphism in middle-aged Belgian men: phenotype distribution and relation to serum lipids and lipoproteins. Atherosclerosis 120: 67-73

[ [7] Burman D, Mente A, Hegele RA, Islam S, Yusuf S, Anand SS (2009) Relationship of the ApoE polymorphism to plasma lipid traits among South Asians, Chinese, and Europeans living in Canada. Atherosclerosis 203 : $192-200$

[8] Dallongeville J, Lussier-Cacan S, Davignon J (1992) Modulation of plasma triglyceride levels by apoE phenotype: a meta-analysis. J Lipid Res 33: 447-454

[9] Das HK, McPherson J, Bruns GAP, Karathanasis SK, Breslow JL (1985) Isolation, characterization and mapping to chromosome 19 of the human apolipoprotein E gene. J Biol Chem 260: 6240-6247

[10] Davignon J, Cohn JS, Mabile L, Bernier L (1999) Apolipoprotein E and atherosclerosis: insight from animal and human studies. Clin Chim Acta 286:115-143

[11] Davignon J, Gregg RE, Sing CF (1988) Apolipoprotein E polymorphism and atherosclerosis. Arteriosclerosis 8:1-21.

[12] Eichner JE, Dunn ST, Perveen G, Thompson DM, Stewart KE, Stroehla BC (2002) Apolipoprotein E polymorphism and cardiovascular disease: a HuGE review. Am J Epidemiol 155: 487-495

[13] Haddy N, De Bacquer D, Chemaly MM, Maurice M, Ehnholm C, Evans A, Sans S, Do Carmo Martins M, De Backer G, Siest G, Visvikis S (2002) The importance of plasma Apolipoprotein E concentration in addition to its common polymorphism on inter-individual variation in lipid levels: results from Apo Europe. Eur J Hum Genet 10 : 841-50

[14] Hokanson JE, Austin MA (1996) Plasma triglyceride level is a risk factor for cardiovascular disease independent of high-density lipoprotein cholesterol level: a meta-analysis of population-based prospective studies. J Cardiovasc Risk 3 : 213-319

[15] Kim HK, Chang SA, Choi EK, Kim YJ, Kim HS, Sohn DW, Oh BH, Lee MM, Park YB, Choi YS (2005) Association between plasma lipids, and apolipoproteins and coronary artery disease: a cross-sectional study in a low-risk Korean population. Int J Cardiol 101: 435-440

[16] Lehtinen S, Lehtimäki T, Sisto T, Salenius JP, Nikkilä M, Jokela H, Koivula T, Ebeling F, Ehnholm C (1995) Apolipoprotein $\mathrm{E}$, serum lipids, myocardial infarction and severity of angiographically verified coronary artery disease in men and women. Atherosclerosis.; $114: 83-91$

[17] Lopez AD, Mathers CD, Ezzati M, Jamison DT, Murray CJ (2006). Global and regional burden of disease and risk factors, 2001: systematic analysis of population health data. Lancet $367: 1747-57$

[18] Mahley RW, Pepin J, Palaoglu KE, Malloy MJ, Kane JP, Bersot TP (2000) Low levels of high density lipoproteins in Turks, a population with elevated hepatic lipase: high density lipoprotein characterization and gender-specific effects of apolipoprotein E genotype. J Lipid Res 41: 1290-1301

[19] Mahley RW, Rall Sc Jr (2000) Apolipoprotein E:far more than a lipid transport protein. Annu Rev Genomics Hum Genet 1:507-37

[20] Mendes-Lana A, Pena GG, Freitas SN, Lima AA, Nicolato RL, Nascimento-Neto RM, Machado-Coelho GL, Freitas RN (2007) Apolipoprotein E polymorphism in Brazilian dyslipidemic individuals: Ouro Preto Study. Braz J Med Biol Res 40 : 49-56

[21] Ordovas JM, Schaefer EJ (2000) Genetic determinants of plasma lipid response to dietary intervention: the role of the APOA1/C3/A4 gene cluster and the APOE gene. Br J Nutr 83 (Suppl 1): S127-136

[22] Panza F, Solfrizzi V, Torres F, Mastrorianni F, Parigi AD, Colaccco AM (1999) Decrease frequency of allele from apolipoprotein E Northern to Southern Europe in Alzheimer's disease patients and centenarians. Neurosci Lett 277: 5356 
[23] Tabatabaei-Malazy O, Fakhrzadeh H, Qorbani M, Amiri P, Larijani B, Tavakkoly-Bazzaz J, Amoli MM (2012) Apolipoprotein $\mathrm{E}$ gene polymorphism and its effect on anthropometric measures in normoglycemic subjects and type 2 diabetes. J Diabetes Metab Disord 8;11(1): 11-18

[24] Vaisi-Raygani A, Kharrazi H, Rahimi Z, Pourmotabbed T (2007) Frequencies of apolipoprotein E polymorphism in a healthy Kurdish population from Kermanshah, Iran. Hum Biol 79(5): 579-87.

[25] Vanuzzo D, Pilotto L, Mirolo R, Pirelli S (2008) Cardiovascular risk and cardiometabolic risk: an epidemiological evaluation. G Ital Cardiol. 9 (4 Suppl 1):6S-17S. (Vanuzzo et al. 2008)

Yin R, Pan S, Wu J, Lin W, Yang D (2008) Apolipoprotein E gene polymorphism and serum lipid levels in the Guangxi Hei Yi Zhuang and Han populations. Exp Biol Med Apr 233(4): 409-418

[26] Yin YW, Sun QQ, Zhang BB, Hu AM, Liu HL, Wang Q, Hou ZZ (2013) Association between apolipoprotein E gene polymorphism and the risk of coronary artery disease in Chinese population: evidence from a meta-analysis of 40 studies. PLoS One 24; 8(6):e66924

[27] Zannis VI, Breslow JL, Utemann G, Mahley RW, Weisgraber KH, Havel RJ, Goldstein JL, Brown MS, Schonfeld G, Hazzard WR (1982) Proposed nomenclature of apoE isoproteins, apoE genotypes, and phenotypes. J Lipid Res 23:911914

[28] Zende PD1, Bankar MP, Kamble PS, Momin AA (2013) Apolipoprotein e gene polymorphism and its effect on plasma lipids in arteriosclerosis. J Clin Diagn Res.; 7(10): 2149 - 2152 